\title{
Corneal sensitivity and correlations between decreased sensitivity and anterior segment pathology in ocular leprosy
}

\author{
Murat A Karaçorlu, Tülay Çakıner, Türkan Saylan
}

\begin{abstract}
Leprosy is one of the leading causes of corneal hyposensitivity. In this article the corneal sensitivity of 143 leprosy patients was examined, and correlations between corneal hyposensitivity and anterior segment pathology were detected. Twenty four healthy volunteers were examined as controls. Various degrees of corneal loss of sensitivity were found in $\mathbf{4 6} \cdot \mathbf{2} \%$ of leprosy patients. Lagophthalmos, chronic lepromatous granulomatous uveitis, iris atrophy, and social blindness were found 4.516.6 times more frequently in eyes which developed severe corneal hyposensitivity.
\end{abstract}

Leprosy, the agent of which is Mycobacterium leprae, is one of the systemic and infectious diseases which mostly involve the eye.$^{1-3}$ Regardless of the portal of entry of the leprosy bacillus the target tissue is the Schwann cells of peripheral nerves. ${ }^{4}$ The bacillus prefers the nerves in areas where the body temperature is low. It may affect the zygomatic branch of nervus facialis and corneal nerves innervated by the ophthalmic branch of the trigeminal nerve. ${ }^{5}$

Although it has long been known that in leprosy corneal sensitivity is decreased, the degree of hyposensitivity, how frequently it appears, whether or not it leads to anaesthesia, and whether it is correlated with anterior segment lesions of leprosy have not been completely evaluated. Various rates of corneal hyposensitivity have been reported, but few of these studies are quantitative, carried out with cotton, and control groups have generally not been included.

In this study we have investigated the actual incidence of corneal hyposensitivity in leprosy and tried to answer those questions.

Department of Ophthalmology, Cerrahpaşa School of Medicine, University of Istanbul

M A Karaçorlu

Istanbul Leprosy

Hospital and Research

Centre, Bakirköy,

Istanbul, Turkey

M A Karaçorlu

T Çakiner

T Saylan

Correspondence to:

Mr M A Karaçorlu, IU

Cerrahpaşa, Tip Fakültesi,

Göz Hast. ABD, Istanbul,

Turkey.

Accepted for publication

16 August 1990

\section{Materials and methods}

The study was carried out in the Department of Ophthalmology, Cerrahpaşa School of Medicine, University of Istanbul, and Istanbul Leprosy Hospital and Research Centre, from June 1986 through June 1989 . A total of 286 eyes were included, from 88 patients with lepromatous leprosy (LL) and 55 patients with borderline lepromatous leprosy (BL). As controls, 48 eyes of 24 healthy adults who had no ocular or systemic diseases and who were not taking any topical or systemic medication when they were included in the study. The study was carried out prospectively, and all ophthalmic examinations and corneal sensitivity measurements were made by the same researcher (MAK). Since there were visible deformities in some of the patients, masking of the investigator was of no use.

The diagnosis of leprosy was established by the case history, clinical and bacteriological tests, and in some cases histopathological investigations at Istanbul Leprosy Hospital and Research Centre. The patients were sent to our working group for ophthalmic evaluation, regardless of whether or not they had any complaints. The cases were classified by the Ridley-Jopling classification. ${ }^{6}$

Systemic and ophthalmic examinations of all patients were undertaken and were recorded on previously prepared forms. Corneal sensitivity was measured by the Cochet-Bonnet aesthesiometer and the intraocular pressure by the Goldmann applanation tonometer.

\section{MEASUREMENT OF CORNEAL SENSITIVITY}

Before the corneal sensitivity measurement was carried out the reason for it and the method were explained to the patient, and his co-operation was sought. The patient, sitting before the biomicroscope, was fixated on an asterisk placed in the distance, lest he should see the filament by means of accommodation. The examination was initiated by a filament $60 \mathrm{~mm}$ in length. The cornea, divided into four quadrants and one central area, was measured first at the centre, and the measurements were then continued clockwise beginning from the lower nasal quadrant. The blinking reflex was not accepted as a response to the contact of the filament. The patient was asked if he felt the contact of the filament, and sometimes the accuracy of his answer was verified by approaching the filament to the cornea but not touching it and asking the patient the same question. The examination began with $60 \mathrm{~mm}$ of filament and was continued by shortening the filament by $5 \mathrm{~mm}$, until the patient responded that he did not feel the contact of the filament. Measurements were carried out in the afternoon from 1300 to 1700 with the same aesthesiometer, in the same setting, and by the same researcher, but the temperature and humidity control of the examination room was not verified.

\section{SEVERITY OF CORNEAL HYPOSENSITIVITY}

The severity of corneal hyposensitivity was graded in the groups included in the study. Those who had a mean corneal sensitivity of 55 $\mathrm{mm}$ or more, measured in five separate quadrants of the cornea, were considered to have normal corneal sensitivity. Corneas having a value of $50-54 \mathrm{~mm}$ were considered as showing a 
Table 1 Corneal sensitivity values in the eyes of leprosy patients and the normal control group in relation to the quadrants of the cornea

\begin{tabular}{llll}
\hline Corneal quadrants & $\begin{array}{l}\text { Leprosy eyes } \\
n: 286\end{array}$ & $\begin{array}{l}\text { Control group } \\
n: 48\end{array}$ & $p$ \\
\hline Centre & $52 \cdot 5(11 \cdot 8)^{\star}$ & $57 \cdot 2(4 \cdot 3)$ & 0.007 \\
Upper temporal & $48 \cdot 0(14 \cdot 1)$ & $54 \cdot 0(6 \cdot 3)$ & 0.004 \\
Upper nasal & $46 \cdot 5(14 \cdot 2)$ & $54 \cdot 5(5 \cdot 4)$ & 0.001 \\
Lower nasal & $52 \cdot 3(11 \cdot 2)$ & $57 \cdot 6(4 \cdot 6)$ & 0.002 \\
Lower temporal & $52 \cdot 4(12 \cdot 3)$ & $57 \cdot 5(4 \cdot 7)$ & 0.005 \\
Average & $50 \cdot 3(12 \cdot 1)$ & $56 \cdot 2(4 \cdot 3)$ & 0.001 \\
\hline
\end{tabular}

^Milimetres, mean (SD).

slight hyposensitivity, those with a value of 40 $49 \mathrm{~mm}$ had a moderate hyposensitivity, and those with a value of $30-39 \mathrm{~mm}$ had a severe hyposensitivity. The patients with a value of $30 \mathrm{~mm}$ or lower were considered to have an advanced degree of corneal hyposensitivity.

Student's $t$ test and analysis of variance were used for statistical analysis.

\section{Results}

The mean age (with SD) of the patients with lepromatous leprosy was $42 \cdot 0(13 \cdot 7)$ years, those with borderline lepromatous leprosy 40.8 (13.0) years, and of the control group 40.7 (12.7) years. The duration of the disease was $20.6(12 \cdot 7)$ years in cases with LL and 18.1 (11.3) years in those with BL.

When the measurements of corneal sensitivity by quadrants of the leprosy patients and of the normal control group were compared, the sensitivity in all the quadrants of the leprosy patients was significantly low, being lowest in the upper nasal quadrant (Table 1).

When the cases of $\mathrm{LL}$ and BL were studied separately, corneal sensitivity in all quadrants was found to be significantly lower in the group with lepromatous leprosy than in the control group. In cases with borderline lepromatous leprosy, though the mean corneal sensitivity was lower than in the control group, the decrease was statistically significant only for the upper nasal quadrant (Table 2).

When the correlation between the duration of the disease and corneal hyposensitivity was investigated in the patients with $\mathrm{LL}$ and $\mathrm{BL}$ leprosy, it was observed that corneal sensitivity was significantly lower in cases with a duration over 15 years as compared with the control group (Table 3).

When the severity of corneal hyposensitivity was evaluated, the proportion of cases in which

Table 2 Corneal sensitivity values in $L L, B L$, and control groups in relation to the quadrants of the cormea

\begin{tabular}{|c|c|c|c|}
\hline Corneal quadrants & $\begin{array}{l}L L \\
n: 176\end{array}$ & $\begin{array}{l}B L \\
n: 110\end{array}$ & $\begin{array}{l}\text { Control group } \\
n: 48\end{array}$ \\
\hline Centre & $\begin{array}{c}50 \cdot 0(13 \cdot 7)^{\star} \\
<0.001\end{array}$ & $\begin{array}{c}56.5(6.2) \\
>0.05\end{array}$ & $57 \cdot 2(4 \cdot 3)$ \\
\hline Upper temporal & $\begin{array}{c}45 \cdot 2(15 \cdot 9) \\
<0 \cdot 001\end{array}$ & $\begin{array}{c}52.6(8.9) \\
>0.05\end{array}$ & $54 \cdot 0(6 \cdot 3)$ \\
\hline Upper nasal & $\begin{array}{c}43 \cdot 6(15 \cdot 8) \\
<0 \cdot 001\end{array}$ & $\begin{array}{c}51.0(9 \cdot 8) \\
<0.05\end{array}$ & $54 \cdot 5(5 \cdot 4)$ \\
\hline & $\begin{array}{c}50.0(13.4) \\
<0.001\end{array}$ & $\begin{array}{c}56.0(6.6) \\
>0.05\end{array}$ & $57 \cdot 6(4 \cdot 6)$ \\
\hline $\begin{array}{l}\text { Lower temporal } \\
\mathrm{p}\end{array}$ & $\begin{array}{c}49 \cdot 8(14 \cdot 3) \\
<0 \cdot 001\end{array}$ & $\begin{array}{c}56 \cdot 6(6.1) \\
>0.05\end{array}$ & $57 \cdot 5(4 \cdot 7)$ \\
\hline $\begin{array}{l}\text { Average } \\
\text { p }\end{array}$ & $\begin{array}{c}47 \cdot 7(13.9) \\
<0.001\end{array}$ & $\begin{array}{c}54.5(6.6) \\
>0.05\end{array}$ & $56 \cdot 2(4 \cdot 3)$ \\
\hline
\end{tabular}

${ }^{\star}$ Millimetres, mean (SD).
Table 3 Correlation between the duration of disease and corneal hyposensitivity in leprosy patients

\begin{tabular}{|c|c|c|c|c|}
\hline \multicolumn{2}{|c|}{$\begin{array}{l}\text { Duration of } \\
\text { disease (yr) } n(\%)\end{array}$} & \multirow{2}{*}{$\begin{array}{l}L L+B L \text { eyes } \\
n: 286\end{array}$} & \multirow{2}{*}{$\begin{array}{l}\begin{array}{l}\text { Control group } \\
n: 48\end{array} \\
56 \cdot 2(4 \cdot 3) \\
56 \cdot 2(4 \cdot 3) \\
56 \cdot 2(4 \cdot 3) \\
56 \cdot 2(4 \cdot 3) \\
56 \cdot 2(4 \cdot 3)\end{array}$} & \multirow{2}{*}{$\begin{array}{l}p \\
>0.05 \\
>0.05 \\
>0.05 \\
<0.01 \\
<0.003\end{array}$} \\
\hline $\begin{array}{l}0 \cdot 5 \\
6-10 \\
11-15 \\
16-20 \\
20\end{array}$ & $\begin{array}{c}36(\% 12 \cdot 6) \\
56(\% 19 \cdot 6) \\
28(\% 9 \cdot 8) \\
48(\% 16 \cdot 8) \\
118(\% 41 \cdot 2)\end{array}$ & & & \\
\hline
\end{tabular}

^Average values, milimetres, mean (SD).

the sensitivity of all five corneal quadrants was 55 $\mathrm{mm}$ or more in the control group was $72.9 \%$. This rate was $53.8 \%$ in patients with leprosy. While the value of corneal sensitivity was below $50 \mathrm{~mm}$ in $6.3 \%$ of patients in the control group, it was $32.2 \%$ in patients with leprosy (Table 4 ). Table 4 shows that, in $46.2 \%$ of patients with leprosy, there were various degrees of corneal hyposensitivity.

In order to investigate the correlation of corneal hyposensitivity with the anterior segment pathology in leprosy, a group of patients with leprosy who had normal corneal sensitivity (154) were compared with another group of patients with leprosy (30) who had an advanced degree of hyposensitivity responding only to the filament length below $30 \mathrm{~mm}$ (4th degree), and the incidence of anterior segment pathology was investigated in both groups (Table 5).

\section{Discussion}

In leprosy the organ most often involved after the skin, nasal mucosa, and peripheral nerves is the eye. The eye is liable to infiltration as soon as the disease agent disseminates through the blood stream. The leprosy bacillus may be present in any part of the eye, but the main lesion is almost always in the structures of anterior segment. Although the primary lesions appear on the cornea, it has been suggested that the earliest affected part is the ciliary body. ${ }^{37}$

The involvement of the trigeminal nerve-ends in the cornea, together with the zygomatic branch of the facial nerve, leads on to the association of corneal hyposensitivity with lagophthalmos, and this in turn indicates how liable the globe has been to the risks inherent in leprosy.

The incidence of corneal hyposensitivity in leprosy has been reported as being between $8 \cdot 1 \%$ and $59 \cdot 2 \%$. As noted above, most of these studies lack valid scientific criteria. Table 6 shows the incidence of corneal hyposensitivity reported in literature.

When the results of our study are examined, it is seen that corneal hyposensitivity in cases with lepromatous leprosy, although the duration of the disease is not different, is more severe than in

Table 4 Severity of corneal hyposensitivity in patients with leprosy and the control group

\begin{tabular}{lcl}
\hline Severity of corneal hyposensitivity & $\begin{array}{l}\text { Leprosy eyes } \\
n: 286\end{array}$ & $\begin{array}{l}\text { Control group } \\
n: 48\end{array}$ \\
\hline Normal (50-60 mm) & $154(\% 53 \cdot 8)$ & $35(\% 72 \cdot 9)$ \\
lst degree (mild) $(50-54 \mathrm{~mm})$ & $40(\% 14 \cdot 0)$ & $10(\% 20 \cdot 8)$ \\
2nd degree (moderate) $(40-49 \mathrm{~mm})$ & $46(\% 16 \cdot 1)$ & $3(\% 6 \cdot 3)$ \\
3rd degree (severe) $(30-39 \mathrm{~mm})$ & $16(\% 5 \cdot 6)$ & - \\
4th degree (advanced)(<30 mm) & $30(\% 10 \cdot 5)$ & - \\
\hline
\end{tabular}


Table 5 Incidence of anterior segment lesions in leprosy patients with normal cormeal sensitivity and leprosy patients with advanced degree of corneal hyposensitivity (4th degree)

\begin{tabular}{lll}
\hline & $\begin{array}{l}\text { Normal } \\
\text { sensitivity }\end{array}$ & $\begin{array}{l}\text { Advanced } \\
\text { hyposensitivity }\end{array}$ \\
$\begin{array}{l}\text { Anterior segment lesions } \\
\text { related to leprosy }\end{array}$ & $\begin{array}{l}154(\% 53 \cdot 8)^{\star} \\
30(\% ~ 10 \cdot 5) \\
\%\end{array}$ \\
\hline Prominent corneal nerves & 32.5 & 23.3 \\
Corneal nerve beading & 33.8 & 20.0 \\
Avascular keratitis & 15.6 & 3.3 \\
Exposure keratitis & 3.9 & 46.7 \\
Acute non-granulomatous uveitis & 13.0 & 6.7 \\
Chronic granulomatous uveitis & $20 \cdot 1$ & 96.7 \\
Iris atrophy & 17.5 & 80.0 \\
Social blindness (<3/60) & 0.6 & 10.0 \\
\hline
\end{tabular}

^The number among leprosy patients.

Table 6 Incidence of corneal hyposensitivity in leprosy according to various studies

\begin{tabular}{|c|c|c|}
\hline Authors & Year & $\%$ \\
\hline $\begin{array}{l}\text { Shields et } a l^{8} \\
\text { Acharya }^{9} \\
\text { Courtright } e t a l^{10} \\
\text { Prasad et al } \\
\text { Ffytch } \\
\text { Tsai and Suryawanshi }{ }^{13} \\
\text { Present study }\end{array}$ & $\begin{array}{l}1971 \\
1978 \\
1984 \\
1984 \\
1984 \\
1985 \\
1989\end{array}$ & $\begin{array}{l}36 \\
59 \cdot 2 \\
20 \\
8 \cdot 1 \\
20 \\
24 \\
46 \cdot 2\end{array}$ \\
\hline
\end{tabular}

cases of borderline lepromatous leprosy and that, the longer the duration of the disease, the worse is the hyposensitivity.

When the topographical distribution of corneal hyposensitivity is examined, the most severe hyposensitivity is found in the upper nasal and temporal quadrants, whether in cases of lepromatous leprosy or of borderline lepromatous leprosy, and that, although there is some hyposensitivity in the corneal centre, this has been relatively less than in the outer quadrants.

Corneal hyposensitivity was examined in the normal state and in four degrees of severity, and it was found that the patients with advanced hyposensitivity who responded to a filament length of less than $30 \mathrm{~mm}$ had had the disease for significantly longer than the leprosy patients with normal corneal sensitivity, and that they became leprous when they were considerably younger.

Various rates of hyposensitivity were determined in $46.2 \%$ of leprous patients. Even when the confidence limit was assumed to be $95 \%$, this rate showed such a high value as $32 \cdot 2 \%$ approximately.

Contrary to mistaken beliefs, leprosy was not found to cause deep corneal hyposensitivity approaching anaesthesia. In this study the number of eyes which had a mean corneal hyposensitivity under $5 \mathrm{~mm}$ was $0.6 \%$. The percentage of such cases has been reported to be $53.3 \%$ in patients with herpetic stromal keratitis. ${ }^{14}$ Leprosy causes less corneal hyposensitivity than herpetic stromal keratitis.

When the leprosy patients with no corneal hyposensitivity and those with advanced corneal hyposensitivity were divided into two groups and examined as to the leprous lesions in the anterior segment, it was found that, in the first group, avascular keratitis occurred approximately five times and acute non-granulomatous uveitis twice as frequently; whereas in the second group, that is, in the cases with advanced hyposensitivity, chronic granulomatous lepromatous uveitis occurred approximately five times, iris atrophy four times, and social blindness 16 times as frequently.

It has been shown that leprosy causes a high percentage of corneal hyposensitivity among patients with the disease in Turkey, and that severe corneal hyposensitivity was more frequent among cases of lepromatous leprosy. The incidence increased with duration of disease, and in patients with advanced corneal hyposensitivity the anterior segment lesions of this disease were found more often.

1 Brand ME, Ffytche TJ. Eye complications of leprosy. In: Hastings RC, ed. Leprosy. Edinburgh, London: ChurchillLivingstone, 1985: 223-42.

2 Rees RJW. The microbiology of leprosy. In: Hastings RC, ed. Leprosy. Edinburgh, London: Churchill-Livingstone, 1985: 31-2.

3 Karaçorlu M, Çakiner T. Lepra hastaliğinda göz problemleri. In: Saylan T, Sütlas M, eds. II. Ulusal Lepra Semineri. Istanbul: Yaylacik Matbaasi, 1986: 99-107.

4 Ridley DS. Leprada histolojinin uygulanmasi, tani, siniflandirma ve reaksiyonlar. In: Saylan T, Sütlas M, eds. siniflandirma ve reaksiyonlar. In: Saylan T, Sütlaş $M$, eds. 1986: 79-89.

5 Ridley MJ. Lepranin mikrobiyoljisi. In: Saylan T, Sütlaş M, eds. II. Ulusal Lepra Semineri. Istanbul: Yaylacik Matbaasi, 1986: 65-71.

6 Ridley DS, Jopling WH. Classification of leprosy according to immunity: a five-group system. Int $\mathcal{F}$ Lepr Other Mycobact Dis 1966; 34: 255-73.

7 Brand MB. Care of the eye in Hansen disease. 2nd ed. Carville, LA: Star, 1987: 3-14.

8 Shields JA, Waring III GO, Monte LG. Ocular findings in leprosy. Am f Ophthalmol 1974; 77: 880-90.

9 Acharya BP. Ocular involvement in leprosy (a study in mining areas of India). Ind F Ophthalmol 1978; 11: 21-4.

10 Courtright $P$, Green R, Pilorski R, Smuony J. A survey of the eye complications of leprosy in South Korea. Lepr Rev 1984; 55: 229-37.

11 Prasad VN, Norain M, Mukhiya RD, Bist HK, Khan MM. A study of ocular complications of leprosy. Indian 7 Lepr 1984; 56: $241-50$

12 Ffytche TJ. The American Peace Corps survey of the ocular complications of leprosy in South Korea, an evaluation and apprasial. Lepr Rev 1984; 55: 239-46.

13 Tsai HH, Suryawanshi N. Ocular complications in patients with leprosy in Karigiri, South India. Lepr Rev 1985; 56: 135-41.

14 Karaçorlu M, Ozyazgan Y, Erçikan C. Herpes simpleks virüsü (HSV) aktif stromal keratitli olgularda klinik özelliker ve kornea duyu değişimleri. Turk Oft Gaz (in press). 